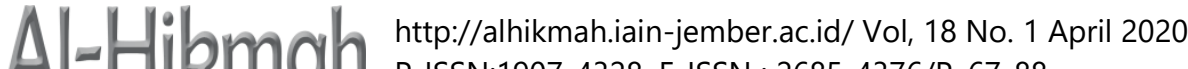

\section{Manajemen Strategi NU TV 9 Menghadapi Televisi Swasta Lokal di Surabaya}

\author{
Abdul Choliq, Mochammad Dawud \\ Institut Agama Islam Negeri Jember \\ choliqbaya@gmail.com
}

\begin{abstract}
Television 9 (TV9) is a private broadcast station owned by the East Java Regional Board of Nahdlatul Ulama (PWNU). TV9 is faced with the NU-style management issues that are thick with pesantren (Islamic boarding school) characteristics, both in terms of human resources and the management system developed by the media company. However, the applied management has actually made TV9 able to reach the maximum audience. The researchers employed qualitative methods. Through such method, this research obtained the results, namely; First, it is owned and managed by Nahdlatul Ulama (NU), as a business entity, TV9 is pursuing profit. TV9 management is managed with the aim of obtaining a very large marketing content for urban Muslims, especially the nahdliyin (NU community). TV9 is able to design programs based on the characteristics and interests of the nahdliyin community so that it gets a positive reception and affects its increase in performance share and ratings. Second, as a religious television station, TV9 prefers "dominant stars" by presenting speakers from the NU circles who have Islamic boarding schools, or students who have many influences in the society. The da'wah program is packed flexibly, lightly but does not leave the substance of the da'wah. Third, there are several factors which becom the primary determinants in the process of making a da'wah program, namely; 1) to attract public interest, 2) to increase ratings and shares, 3) to persuade companies to advertise their products through da'wah broadcast on TV9.
\end{abstract}

Keywords: Strategic Management, Local Television Station.

\begin{abstract}
Abstrak
Televisi 9 (TV9) adalah lembaga penyiaran swasta yang dimiliki oleh Pengurus Wilayah Nahdlatul Ulama (PWNU) Jawa Timur. TV9 dihadapkan pada persoalan manajemen ala NU yang kental dengan corak pesantren, baik secara SDM maupun sistem manajemen yang dikembangkan perusahaan. Namun manajemen yang diterapkan justru membuat TV9 mampu menjangkau pemirsanya secara maksimal. Penelitian ini menggunakan metode kualitatif. Melalui pembacaan itu, penelitian ini memperoleh hasil yaitu; Pertama, meski dimiliki dan dikelola oleh Nahdlatul Ulama (NU), sebagai entitas bisnis TV9 bertujuan mengejar profit. Manajemen TV9 dikelola dengan tujuan untuk mendapatkan pangsa pasar yang sebesar-besarnya terhadap warga muslim kota (urban moslem) khususnya warga nahdliyin. TV9 mampu mendesain program acara dengan karakteristik dan kepeminatan warga nahdliyin sehingga mendapatkan penerimaan yang positif dan berpengaruh terhadap
\end{abstract}


naiknya performance share and rating. Kedua, sebagai televisi religi, TV9 lebih memilih star dominant dengan menghadirkan narasumber dari kalangan NU yang memiliki pesantren, santri yang banyak dan berpengaruh di masyarakat. Program acara dakwah dikemas dengan fleksibel, ringan namun tak meninggalkan substansi dakwah. Ketiga, adapun faktor-faktor yang menjadi determinasi primer dalam proses pembuatan program acara dakwah adalah; 1) menarik animo masyarakat, 2) menaikkan rating and share, 3) memancing pihak iklan untuk menyosialisasikan produknya melalui siaran dakwah di TV9.

Kata Kunci: Manajemen Strategi, Televisi Lokal.

\section{Pendahuluan}

Perkembangan teknologi informasi akhir-akhir ini menuntut model dakwah melalui media yang beragam pula. Ia telah menciptakan ruang sosial baru yang tidak memiliki batas, baik secara geografis, perbedaan tingkat ekonomi, tingkat pendidikan, agama, politik, maupun sosial-budaya. Lantas, dakwah kemudian dikemas sedemikian rupa agar terlihat lebih menarik. Seperti melalui lagu-lagu religi, kasidah, termasuk ceramah yang ditampilkan dalam media-media televisi dan media sosial lainnya. Termasuk berbagai aplikasi yang bisa digunakan sebagai sarana untuk menunjang efektivitas proses dakwah.

Salah satu dari teknologi informasi media massa yang banyak diminati oleh masyarakat adalah televisi. Tayangan-tayangan yang disampaikan di dalamnya dapat memberikan pengaruh sedikit banyak kepada khalayaknya. Padahal, pekerjaan media massa adalah menceritakan peristiwa-peristiwa, maka kesibukan utama media massa adalah mengonstruksi berbagai realitas yang akan disiarkan. Media menyiarkan realitas yang terjadi hingga menjadi cerita atau wacana yang bermakna. ${ }^{1}$

Jatuhnya rezim Orde Baru yang diikuti dengan reformasi telah membuka keran kebebasan berekspresi. Salah satu produk yang penting adalah lahirnya Undang-Undang nomor 32 tahun 2002 tentang Penyiaran. Salah satu amanah dari undang-undang penyiaran adalah didirikannya lembaga penyiaran lokal yang siarannya terbatas pada satu area layanan tertentu. ${ }^{2}$

Pada tahun 2007, Komisi Penyiaran Indonesia Daerah (KPID) Jatim telah mengeluarkan pengumuman tentang periodesasi pendaftaran lembaga penyiaran di Jatim. Lembaga-lembaga penyiaran, baik televisi maupun radio, diminta untuk mendaftarkan ulang permohonan izinnya agar diproses lebih lanjut sampai dikeluarkannya izin penyelenggaraan penyiaran. Ketika itu tercatat sekitar 420 lembaga penyiaran radio dan 102 lembaga penyiaran televisi mengajukan izin

${ }^{1}$ Ibnu Hamad, Konstruksi Realitas Politik Dalam Media Massa, (Jakarta: Granit, 2004), hal. 11 .

${ }^{2}$ Undang-Undang nomor 32 tahun 2002 tentang Penyiaran pasal 6 ayat 3. 
penyelenggaraan penyiaran, termasuk lembaga penyiaran televisi lokal. ${ }^{3}$ Dari jumlah itu tidak semuanya memenuhi persyaratan. Tercatat, saat ini tinggal 34 lembaga penyiaran televisi lokal yang sudah diproses izin penyiarannya. ${ }^{4}$

Di Surabaya, ada 22 televisi yang bersiaran. Mereka ada yang berpusat di Jakarta, juga di Surabaya yang memiliki jaringan di beberapa tempat, dan ada yang berdiri sendiri sebagai televisi lokal yang tidak berjaringan dan hanya bersiaran di Surabaya. Televisi-televisi yang berpusat di Jakarta adalah RCTI, SCTV, INDOSIAR, TRANS TV, TRANS7, ANTV, TV One, Metro TV, MNC TV, Global TV dan TVRI Program Nasional. Belakangan, jumlah itu bertambah dengan mengudaranya Kompas TV, RTV dan NET.TV. Sedangkan televisi yang berpusat di Surabaya dan memiliki jaringan di beberapa daerah adalah JTV, I-News TV/MHTV, Surabaya TV/Bali TV, TV9 dan BBS TV. Televisi-televisi yang berdiri sendiri di Surabaya dan tidak memiliki jaringan tinggal Arek TV saja. ${ }^{5}$

Televisi-televisi itu semuanya masih bersiaran sesuai dengan ketentuan peraturan perundang-undangan. Ragam acara yang disusun pun juga semakin bervariasi, termasuk program dakwah Islam yang ditayangkan di beberapa televisi. Pada umumnya, program tentang dakwah Islam di televisi sudah sejak awal dicantumkan dalam proposal pengajuan izin penyiaran. Namun ada juga televisi yang tidak melakukannya. ${ }^{6}$

Televisi, sebagaimana ditulis Robin Brown, memiliki dampak yang luar biasa. Ia bisa menjelajah dari perkotaan hingga ke pedesaan dan mempengaruhi masyarakat desa bahkan sampai kepada kelompok masyarakat yang berusia lanjut sekalipun. ${ }^{7}$ Raymond Williams menyebutkan bahwa televisi adalah teknologi komunikasi massa. Penggunaan kata massa yang terkesan deskriptif adalah problem perbenturan (contentious problem) dari relasi-relasi sosial yang riil yang di dalamnya sistem-sistem komunikasi modern beroperasi. ${ }^{8}$

TV 9 Surabaya adalah satu-satunya televisi swasta di Indonesia yang memiliki karakter pemirsa komunitas. Televisi ini didirikan oleh Pengurus Wilayah

${ }^{3}$ Database pendaftaran lembaga penyiaran KPID Jawa Timur periode 21 Oktober-21 Desember 2007.

${ }^{4}$ Data diperoleh dari KPID Jawa Timur yang menguraikan jumlah lembaga penyiaran yang sudah berproses. Tahapan proses perizinan sesuai dengan Peraturan Menteri Komunikasi dan Informatika nomor 28 tahun 2008 tentang Tata Cara Penyelenggaraan Penyiaran ada beberapa tahap, diantaranya mulai dari pengajuan proposal permohonan, verifikasi administratif, verifikasi faktual, rekomendasi kelayakan (RK), izin stasiun radio (ISR), izin penyiaran, evaluasi uji coba siaran (EUCS) dan izin penyelenggaraan penyiaran (IPP).

${ }^{5}$ Database Perizinan KPID Jatim tahun 2016.

${ }^{6}$ Hampir setiap proposal pengajuan izin penyiaran yang disampaikan ke KPI dan KPID Jatim memuat adanya program dakwah Islam.

7 Robin Brown dalam Boundaries in Question, editor: John McMillan dan Andrew Linklater, (USA: Pinter Publisher's London \& New York, 1995), hal. 54.

8 Raymond Williams, Televisi, terjemahan dari buku Television: Technology and Cultural Form, (Yogyakarta: Resist Book, 2009), hal 166. 
Nahdlatul Ulama (PWNU) Jawa Timur dalam upaya sebagai strategi dakwah Islam ahlusunnah wal jamaah annahdliyah melalui media penyiaran televisi. ${ }^{9}$

NU sebagai organisasi keagamaan dan kemasyarakatan kian tahun menghadapi tantangan yang tidak mudah. Perkembangan teknologi informasi dan komunikasi telah mengubah wajah dunia, dari lokalitas atau kedaerahan, menjadi fenomena global, lebih-lebih dalam penyampaian pesan-pesan dakwah. Sisi positif tentu ada dari fenomena globalisasi ini. Kemudahan-kemudahan mendapatkan informasi, baik melalui internet, jejaring sosial sebagaimana facebook, twitter, instagram, youtube atau bahkan yang bersifat private yang kesemuanya tidak mungkin bisa dilakukan puluhan tahun lalu. Aspek positif ini, tentu akan meningkatkan produktivitas dan up to date terhadap perkembangan zaman. Namun di sisi lain, ancaman siap menanti. Globalisasi menyebabkan apapun bisa diakses oleh masyarakat, baik melalui media cetak, internet dan tentu juga televisi. Sementara penyedia konten atau program media, dikuasai oleh dunia barat yang jauh lebih maju. Kalau pun ada program televisi yang dibuat oleh anak bangsa, melalui stasiun yang ada, maka pendekatan, orientasi dan gaya produksinya semua berkiblat pada cara pandang dan mazhab entertainment yang sering kali tak sesuai dengan nilai, karakter, dan akhlak yang ditanamkan para ulama terdahulu.

Kekhawatiran akan dampak negatif globalisasi inilah yang kemudian diterjemahkan oleh PWNU Jatim dengan mendirikan TV9 di Surabaya. Dalam perkembangannya, TV9 menjelma menjadi televisi yang berkarakter swasta/komersial. Begitu juga dengan proses perizinan yang dilakukannya. Televisi ini telah mengantongi izin penyelenggaraan penyiaran (IPP) dari Kementerian Komunikasi dan Informatika dan secara resmi bersiaran di wilayah Surabaya Greater mulai tahun $2010 .^{10}$

Sebagai televisi yang didirikan dan dikelola oleh PWNU Jawa Timur, televisi ini memiliki misi untuk menyebarluaskan paham ahalussunnah wal jamaah annahdliyah kepada masyarakat di wilayah yang bisa diterima siarannya dengan baik. $^{11}$ Namun, jika dirunut, asal muasal dari pendirian televisi ini sebenarnya berangkat dari munculnya fenomena televisi swasta Jakarta yang berjaringan di daerah. Televisi-televisi swasta itu dinilai tidak bisa mengakomodasi kepentingan dakwah NU sebagai warga muslim mayoritas. ${ }^{12}$ Bahkan cenderung memojokkan.

${ }^{9}$ Hakim Jayli, Televisi Kaum Santri: Konsep Baru Bisnis dan Tayangan Televisi di Gerbang Era Televisi Digital, (Surabaya: TV9 Nusantara, 2012), hal. 6.

${ }^{10}$ Surabaya Greater adalah sebutan untuk wilayah Surabaya dan sekitarnya yang terdiri atas Sidoarjo, Gresik, Lamongan, Bangkalan, Mojokerto, Pasuruan dan Probolinggo. Sebutan ini juga merujuk pada wilayah layanan televisi swasta terestrial Surabaya dan sekitarnya sebagaimana yang diatur dalam Keputusan Menteri Perhubungan Nomor 76 tahun 2003 tentang Frekuensi TV Analog.

${ }^{11}$ A. Hakim Jayli, Op. Cit., hal. 4

${ }^{12}$ Memang tidak ada data yang pasti berapa jumlah warga NU di Indonesia. Beberapa sumber juga menyebut angka yang berbeda. Seperti Mohammad Sobary dalam buku "NU dan 
Selain itu, gencarnya arus globalisasi dan liberalisasi juga berdampak pada semakin terpinggirkannya konten-konten acara dakwah. Program-program acara yang bernuansa untuk kepentingan ekonomi liberal semakin gencar dibuat dan ditayangkan. Sehingga, sisi-sisi rohani dan spiritualitas kurang mendapatkan tempat di media-media penyiaran tersebut.

Namun, mendirikan lembaga penyiaran televisi dan menjalankannya bukanlah hal yang mudah. Dunia penyiaran adalah hal yang baru bagi komunitas nahdliyin. Lebih-lebih menjamin keberlangsungan bersiaran TV9 sepanjang waktu. Manajemen organisasi yang banyak dilakukan PWNU Jatim terhadap kelembagaan NU tidak banyak memberikan kontribusi dalam menjalankan TV9.

Lembaga penyiaran, bagaimanapun juga, merupakan sebuah entitas industri. Ia adalah sebuah bisnis yang harus dijaga keberlangsungannya. Hal ini sangat berbeda dengan semangat pengurus wilayah NU Jawa Timur yang selama ini mengurusi ormas terbesar di Indonesia itu dengan semangat sosial dan keikhlasan tanpa menghitung seberapa besar keuntungan ekonomi dan bisnis yang dihasilkan dari beraktivitas di NU. Kondisi seperti ini menjadi tantangan tersendiri bagi manajemen TV9 yang seluruhnya diisi personil dari warga nahdliyin. Lebih-lebih dalam menghadapi persaingan dengan lembaga penyiaran swasta Jakarta yang berjaringan di daerah-daerah termasuk di Surabaya.

Dalam media penyiaran diperlukan manajemen dan kemampuan manajerial yang bisa mengarahkan perusahaan pada tujuan utama, yakni profit. Faktor-faktor yang menyertainya juga banyak dan kompleks.

\section{Pembahasan}

\section{Strategi Manajemen Penyiaran}

Strategi pada hakikatnya adalah perencanaan (planning) dan manajemen (management) untuk mencapai suatu tujuan. Strategi merupakan rencana tindakan jangka panjang yang digunakan sebagai pedoman bagi kegiatan-kegiatan yang telah direncanakan sebelumnya dengan harapan dapat mencapai suatu hasil yang maksimal. Sehingga, strategi memiliki arti pola-pola berbagai tujuan dan kebijaksanaan serta rencana-rencana untuk mencapai tujuan yang telah ditetapkan sedemikian rupa dengan memperhatikan kekuatan internal dan eksternal organisasi.

Keindonesiaan" menyatakan jumlah warga NU sekitar 60 juta orang. Sedangkan Gus Dur menyebut jumlah warga NU adalah separuh dari jumlah umat Islam di Indonesia atau sekitar 120 juta jiwa. Survei yang dilakukan IndoBaromater menyebutkan sekitar 75 persen warga muslim yang disurvei mengaku warga nahdliyin, yang berarti angkanya sekitar 143 juta jiwa. LSI juga menyebut warga NU adalah 36,5 persen dari jumlah penduduk Indonesia. Sementara itu, Alvara Research Center menemukan data survei bahwa penduduk muslim Indonesia 50,3\% mengaku berafiliasi dengan NU atau sekitar 79,04 juta jiwa. 
Tujuannya agar program yang akan dilaksanakan oleh organisasi menjadi jelas. ${ }^{13}$

Manajemen strategis merupakan proses atau rangkaian kegiatan pengambilan keputusan yang bersifat mendasar dan menyeluruh, disertai penetapan cara melaksanakannya, yang dibuat oleh pimpinan dan diimplementasikan oleh seluruh jajaran di dalam suatu organisasi, untuk mencapai tujuan. Manajemen strategis adalah kumpulan dan tindakan yang menghasilkan perumusan (formulasi) dan pelaksanaan (implementasi) rencana-rencana yang dirancang untuk mencapai sasaran-sasaran organisasi. ${ }^{14}$

Nawawi bahkan menyebut manajemen strategis adalah perencanaan berskala besar yang berorientasi pada jangkauan masa depan yang jauh (disebut visi), dan ditetapkan sebagai keputusan pimpinan tertinggi (keputusan yang bersifat mendasar dan prinsipil), agar memungkinkan organisasi berinteraksi secara efektif (disebut misi), dalam usaha menghasilkan sesuatu (perencanaan operasional untuk menghasilkan barang dan/atau jasa serta pelayanan) yang berkualitas, dengan diarahkan pada optimalisasi pencapaian tujuan (disebut tujuan strategis) dan berbagai sasaran (tujuan operasional) organisasi. ${ }^{15}$

Sedangkan Gregory G. Dees menjelaskan bahwa manajemen strategi adalah kombinasi dari tiga kegiatan; analisis strategi, perumusan strategi dan strategi implementasi. Hal itu berarti manajemen strategis merupakan suatu sistem sebagai satu kesatuan yang memiliki berbagai komponen saling berhubungan dan saling mempengaruhi, dan bergerak secara serentak (bersama-sama) ke arah yang sama pula. Komponen pertama adalah perencanaan strategi dengan unsur-unsurnya yang terdiri dari visi, misi, tujuan dan strategi utama organisasi. Sedangkan komponen kedua adalah perencanaan operasional dengan unsur-unsurnya sasaran dan tujuan operasional, pelaksanaan fungsi-fungsi manajemen berupa fungsi pengorganisasian, fungsi pelaksanaan dan fungsi penganggaran, kebijaksanaan situasional, jaringan kerja internal dan eksternal, fungsi kontrol dan evaluasi serta umpan balik.

Dengan demikian manajemen strategis dapat dimaknai:

1. Manajemen strategi diwujudkan dalam bentuk perencanaan berskala besar dalam arti mencakup seluruh komponen di lingkungan sebuah organisasi yang dituangkan dalam bentuk rencana strategis (renstra) yang dijabarkan menjadi perencanaan operasional, yang kemudian dijabarkan pula dalam bentuk program kerja dan proyek tahunan.

2. Renstra berorientasi pada jangkauan masa depan.

3. Visi, misi, pemilihan strategi yang menghasilkan strategi induk, dan tujuan

${ }^{13}$ Effendy, Onong Uchyana, Dinamika Komunikasi, (Bandung: Remaja Rosdakarya, 2008), hal. 32.

${ }^{14}$ Pearch. Robinson, Manajemen Strategik: Formulasi, Implementasi, dan Pengendalian, (Jakarta: Binarupa Aksara, 1997), hal. 47-48.

${ }^{15}$ Hadari Nawawi, Manajamen Sumber Daya Manusia untuk Bisnis yang Kompetitif, (Yogyakarta: Gajah Mada University Press, 2003), hal. 32-33.

72 | Abdul Choliq, Mochammad Dawud 
strategi organisasi/perusahaan untuk jangka panjang merupakan acuan dalam merumuskan rencana strategi, namun dalam teknik penempatannya sebagai keputusan manajemen puncak secara tertulis semua acuan tersebut terdapat di dalamnya.

4. Renstra dijabarkan menjadi rencana operasional yang antara lain berisi program-program operasional termasuk proyek-proyek, dengan sasaran jangka sedang masing-masing juga sebagai keputusan manajemen puncak.

5. Penetapan renstra dan rencana operasi harus melibatkan manajemen puncak karena sifatnya sangat mendasar/prinsipil dalam pelaksanaan seluruh misi organisasi, untuk mewujudkan, mempertahankan dan mengembangkan eksistensi jangka sedang termasuk panjangnya.

6. Implementasi strategi dalam program-program termasuk proyek-proyek untuk mencapai sasarannya masing-masing dilakukan melalui fungsi-fungsi manajemen lainnya yang mencakup pengorganisasian, pelaksanaan, penganggaran dan kontrol.

Secara rinci, manajemen strategi memiliki tujuan, yaitu:

a. Memberikan arah pencapaian tujuan organisasi/perusahaan. Dalam hal ini manajer startegi harus mampu menunjukkan kepada semua pihak kemana arah tujuan organisasi/perusahaan. Karena arah yang jelas akan dapat dijadikan landasan untuk pengendalian dan mengevaluasi keberhasilan.

b. Membantu memikirkan kepentingan beberapa pihak, organisasi/perusahaan harus mempertemukan kebutuhan berbagai pihak, pemasok, karyawan, pemegang saham, pihak perbankan, dan masyarakat luas lainnya yang memegang peranan terhadap sukses atau gagalnya perusahaan.

c. Mengatasi setiap perubahan kembali secara merata, Manajemen strategi memungkinkan eksekutif puncak untuk mengantisipasi perubahan dan menyiapkan pedoman dan pengendalian, sehingga dapat memperluas kerangka waktu/berpikir mereka secara perspektif dan memahami kontribusi yang baik untuk hari ini dan hari esok.

d. Berhubungan dengan efisiensi dan efektivitas, Tanggung jawab seorang manajer bukan hanya mengonsentrasikan terhadap kemampuan atas kepentingan efisiensi, akan tetapi hendaknya juga mempunyai perhatian yang serius agar bekerja keras melakukan suatu secara lebih baik dan efektif. ${ }^{16}$

Saat menghadapi tingkat persaingan yang tinggi, sebuah lembaga penyiaran harus memiliki manajemen khusus agar disukai oleh pemirsanya dan mendapatkan iklan yang memadai. Menurut Henry Fayol, manajemen merupakan proses

${ }^{16}$ M. Suwandyanto, Manajemen Strategi dan Kebijakan Perusahaan, (Jakarta: Salemba Empat, 2010), hal. 23-24. 
menginterpretasikan, mengoordinasikan sumber daya, sumber dana, dan sumbersumber lainnya untuk mencapai tujuan dan sasaran melalui tindakan-tindakan perencanaan, pengorganisasian, penggerakan, dan pengawasan. ${ }^{17}$

\section{Adu Konsep Ekonomi Politik Media}

Media penyiaran televisi bukanlah suatu bidang yang baru dan masih sepi dari persaingan. Segala bentuk kompetisi justru ada di bidang ini. Masing-masing televisi beradu untuk menyuguhkan program-program yang terbaik, program yang laing diminati oleh masyarakat. Tujuannya tak lain dan tak bukan adalah agar mendapatkan iklan yang sebanyak-banyaknya. Fenomena pengerahan berbagai sumber daya yang dimiliki untuk menghasilkan produk program yang yang menyedot penonton dan menyebarluaskannya melalui ruang publik bisa dibaca dengan menggunakan pisau analisa ekonomi politik edia. Usaha ini merupakan salah satu upaya untuk menemukan titik singgung yang konseptual untuk melihat keterkaitan secara massif antara pengoptimalan sumber daya TV9 dalam upaya bersaing dengan televisi-televisi yang lain.

Jika Raymond Williams memaknai televisi sebagai the medium is the message, ${ }^{18}$ maka dalam perspektif ekonomi politik media penyiaran, televisi tak sebatas dimaknai sebagai penyuplai pesan/informasi. Media massa adalah kelas yang mengatur. Demikianlah premis dari teori Marxis tentang posisi media dalam percaturan sistem kapitalisme modern. ${ }^{19}$

Ekonomi politik media memusatkan perhatiannya pada hubungan dominasi dan penguasa ekonomi dalam mempengaruhi institusi sosial lain, termasuk media massa. Hingga hubungan kepengaruhan tersebut dapat mempengaruhi sistem produksi, distribusi dan konsumsi media massa. Saling terhubung dan pengaruh ini menjadi sebuah indikasi bahwa televisi sebagai media massa telah menjadi primadona pada ranah publik. Kebutuhan masyarakat yang begitu besar terhadap media di satu sisi, serta keberagaman media massa itu sendiri di sisi lain, secara langsung maupun tidak, telah mempunyai nuansa kepentingan yang begitu kental sehingga berimbas kepada "ketidakmurnian".

Ketidakmurnian kepentingan ini dapat ditelisik melalui intervensi pemilik modal terhadap posisi media massa yang dewasa ini kian menunjukkan nuansa orientasi pasar (market oriented) yang begitu kental. Definisi market dalam konteks ini tak hanya dimaknai sebagaimana makna lawasnya, sehingga tak hanya sebatas pengerukan ekonomi, tetapi juga sebagai lokomotif ideologi politik oleh pemilik modal yang berkepentingan. Argumentasi ini menunjukkan buktinya dengan sangat

${ }^{17}$ Totok Djuroto, Manajemen Penerbitan Pers, (Bandung: Remaja Rosdakarya, Cet. III, 2004), hal. 96.

${ }^{18}$ Raymond Williams, Op. Cit., hal. 175.

${ }^{19}$ Agus Sudibyo, Op. Cit. hal. 1. 
konkret saat pemilihan presiden pada 2014 lalu, manakala bangsa Indonesia menghadapi pemilihan umum untuk menentukan presiden, maka eksistensi televisi berita seperti Metro TV dan TV One menjadi pertarungan ideologi politik yang sangat tampak dipermukaan.

Kedua stasiun televisi nasional tersebut telah menjadi "corong sosialisasi" para calon tertentu untuk mendapatkan simpati dan empati dari masyarakat umum. Di sinilah letak kedahsyatan dan efektifitas media massa, khususnya televisi dalam mempengaruhi dan mengkonstruk pemikiran masyarakat kelas menengah. Ironisnya, kesadaran masyarakat tentang begitu intimnya hubungan antara media massa dengan kepentingan politik dan pemilik modal sangat minim, bahkan hampir pada "titik nol". ${ }^{20}$ Sehingga, dalam membaca orientasi media massa yang bergeser dari penyuplai informasi menjadi alat propaganda politik dan penggaet ekonomi komersial, maka menjadi penting untuk mengutip pendapat salah seorang pengamat ekonomi politik media, Vincent Mosco yang pernah menyatakan:

"Political economy is the study of the social relations, particularly the power relations, that mutually constitute the productions, distribution, and consumption of resource, including communication resources". ${ }^{21}$

Dari perspektif di atas, Mosco menegaskan bahwa ekonomi politik media merupakan studi dalam hubungan interaksi sosial, yang merupakan bagian dari hubungan kekuatan melalui proses produksi, distribusi dan konsumen sumber berita, termasuk sumber komunikasi itu sendiri. ${ }^{22}$

\section{Paradigma Baru Dakwah NU Jatim}

Melahirkan TV9 bagi PWNU Jatim bukanlah hal yang mudah. Rekomendasi untuk mendirikan stasiun televisi sendiri bahkan muncul di empat kali forum Konferensi Wilayah Nahdlatul Ulama (Konferwil NU) Jatim. Rekomendasi itu muncul karena ekses negatif dari tayangan televisi-televisi Jakarta yang tidak mendidik dan tidak mencerminkan kepribadian Islam sebagai agama yang dianut oleh sebagian besar penduduk Indonesia. Tuntutan pendirian stasiun televisi semakin memuncak tatkala televisi Jakarta membuat program acara bertema dakwah namun isinya lebih banyak menyudutkan amaliyah warga NU. ${ }^{23}$

Dalam benak para peserta Konferwil NU Jatim, televisi itu akan berisi acara-

\footnotetext{
${ }^{20}$ Ibid, hal. ii.

${ }^{21}$ Vincent Mosco, The Political Economy of Communication, (Singapore: SAGE Publications Asia-Pacific), hal.2.

${ }^{22}$ Ibid, hal. 1.

${ }^{23}$ Beberapa program acara dakwah yang ditayangkan dan berisi konten yang pernah menyudutkan amaliyah warga NU adalah "Khazanah" dan "Berita Islam Masa Kini”. Di antara isinya adalah mengharamkan ziarah kubur, dan tidak sampainya tawassul kepada orang yang sudah meninggal.
} 
acara keagamaan khususnya dakwah Islam yang berpedoman pada akidah ahlusunnah wal jamaah annahdliyah dan memberikan tuntutan kepada umat Islam khususnya warga NU di Jatim. Hal itu dirasa mutlak dilakukan karena sebagian besar masyarakat Jatim adalah nahdliyin. Rencananya, kantor dan studio televisi tersebut berada di Surabaya sehingga bisa bersiaran di ibukota provinsi sekaligus bisa menjangkau daerah-daerah di sekitarnya, seperti Gresik, Lamongan, Bangkalan, Sidoarjo, Pasuruan, Probolinggo dan Mojokerto. ${ }^{24}$

Ide itu mengalami kebuntuan karena saat itu pemerintah tidak sedang membuka pendaftaran lembaga penyiaran televisi baru, lebih-lebih di Surabaya yang sudah memiliki banyak lembaga penyiaran televisi. Ada 6 lembaga penyiaran televisi dari Jakarta yang bersiaran berjaringan di Surabaya. Mereka adalah RCTI, SCTV, Indosiar, TPI/MNC TV, TVRI, dan ANTV. Belum lagi televisi-televisi dari Jakarta yang lahir setelah reformasi dan juga bersiaran di Surabaya tanpa izin resmi kala itu. Ditambah munculnya stasiun TV lokal, seperti JTV Surabaya. Berbagai lobi dilakukan, khususnya terhadap para pengambil kebijakan. Menteri Komunikasi dan Informatika kala itu, Muhammad Nuh akhirnya merancang dikeluarkannya Peraturan Menkominfo yang isinya membuka peluang usaha untuk lembaga penyiaran swasta televisi untuk mendaftar.

Di Pasuruan, ada sebuah lembaga penyiaran televisi yang dimiliki oleh tokoh NU Pasuruan dan bersiaran reguler. Namanya PAS TV, yang merupakan kepanjangan dari Pasuruan Televisi. Lembaga Penyiaran itu didirikan oleh Misbahul Munir, seorang tokoh NU Pasuruan yang juga pengusaha dan aktif di bidang politik. Seorang anak muda dipercaya mengelola televisi itu dan memastikan bersiaran setiap hari dengan konten-konten acara yang bernuansa nahdliyin. Dialah Ahmad Hakim Jayli, yang kelak kemudian menjadi direktur utama TV9.

Pasuruan dan Surabaya masih satu wilayah layanan siaran. Sehingga pengambil kebijakan waktu itu menyarankan agar PAS TV ditarik ke Surabaya dan dijadikan televisi milik PWNU Jatim. Hingga, tahun 2010, berdirilah TV9 Surabaya yang berkantor di Jalan Raya Darmo Surabaya. Demikianlah jalan panjang pendirian TV9 yang diniati untuk menyaingi konten-konten agama TV-TV Jakarta yang tidak ramah dengan amal ibadah warga nahdliyin.

Content of the media always reflects who finance them (isi media adalah apa yang dikatakan pemilik media). Ungkapan Dennis McQuail sangat pas menggambarkan tayangan-tayangan program acara televisi. Begitu pula yang

${ }^{24}$ Penjelasan ini disampaikan Ketua PWNU Jatim periode 2008-2013, dan 2013-2018 yang juga komisaris utama dan pendiri TV9, KH Mutawakkil Alallah dalam beberapa kesempatan. Termasuk saat menyampaikan laporan pertanggung jawaban sebagai Ketua PWNU Jatim periode 2008-2013 pada momen Konferwil NU Jatim di Pondok Pesantren Bumi Sholawat Sidoarjo, pada 1-2 Juni 2013. 
dialami TV9. Ia mencerminkan model cara beragama Islam ala NU. TV9 adalah media penyiaran yang awalnya sungguh-sungguh dimiliki oleh NU. Dalam hal ini, para pemilik saham adalah orang-orang NU dan PWNU Jatim. Kepemilikan saham terbagi atas dua macam. Pertama, saham yang dimiliki oleh PWNU Jatim melalui PT Dakwah Inti Media sebesar 30 persen. Kedua, saham yang dimiliki oleh perorangan. Saham yang dimiliki PWNU Jatim sebagian besar adalah berupa aset, yakni gedung yang terletak di Jalan Raya Darmo Surabaya. Sedangkan saham yang dimiliki perorangan berupa dana yang disetor untuk modal dan operasional TV9 sejak berdiri. $^{25}$

Televisi adalah industri yang padat modal. Ia akan terus menyedot dana dari para pemilik saham hingga mendapatkan pemasukan yang memadai untuk operasional dan bahkan keuntungan perusahaan. Hal ini juga yang dialami TV9 agar proses produksi terus berjalan, dana operasional digelontor. Jumlah pesaham semakin bertambah. Tak kurang dari 50 orang yang menjadi pesaham TV9 dari 70 persen saham perorangan. Sehingga akhirnya pada tahun 2013, para pesaham angkat tangan. TV9 diupayakan mendapatkan suntikan dana segar dengan prinsip kerjasama. Sebanyak 70 persen saham kemudian dilepas kepada PT Siantar Top. Sebuah perusahaan makanan ringan yang berkomitmen tetap menjaga konten TV9 sebagai televisi dakwah NU dan tidak mengubah apapun dalam struktur organisasi dan manajemen. ${ }^{26}$

Kini, TV9 bersiaran 20 jam. Lebih panjang jam tayangnya daripada awalawal beroperasi. Dari semua waktu tayang, sebagian besar digunakan untuk kepentingan dakwah NU. Sebagian lainnya untuk memutar iklan. Di sebagian waktu untuk berdakwah ala NU itu, dijadwal secara reguler dan tentatif acara-acara dakwah yang sangat berkarakter NU. Seperti pengajian umum, pengajian kitab kuning, pengajian tentang ahlusunnah wal jamaah annahdliyah. Para ulama NU yang selama ini hanya menyeru dakwah melalui mimbar-mimbar pengajian dari kampung ke kampung kemudian direkam, diberi slot waktu reguler. Tidak hanya para kyai, melainkan juga Bu Nyai, Ning atau ustadzah. TV9 memindahkan pengajian di musala-musala kampung ke layar kaca. ${ }^{27}$

${ }^{25}$ Wawancara dengan A. Hakim Jayli, 2 Desember 2018.

${ }^{26}$ Hakim Jayli menceritakan, pilihan sebagai pesaham jatuh ke tangan PT Siantar Top bukanlah tiba-tiba dan sesaat. Sebelum melepas 70 persen saham TV9, pihak manajemen dan dewan komisaris sudah menjajaki satu persatu perusahaan yang berniat membeli saham TV9. Mulai dari perusahaan media hingga yang tidak ada hubungannya dengan media. Pihak TV9 menyodorkan perjanjian bahwa meski sebagian besar saham dimiliki PT lain, namun manajemen dan konten TV9 tidak akan berubah. Persyaratan itulah yang disepakati oleh PT Siantar Top sehingga dipilih sebagai pemilik saham.

${ }^{27}$ Menurut Hakim Jayli, sebenarnya teknik tersebut adalah sebuah cara juga agar biaya produksi tidak terlalu tinggi. Ia mengibaratkan TV9 adalah radio yang bergambar. Maksudnya, program-program acara dakwah sebagaimana model yang diputar di stasiun radio, namun karena 
Program acaranya pun semakin variatif. Tidak hanya pengajian, melainkan juga acara-acara lain, seperti berita dan hiburan. Bahkan, untuk program berita, TV9 membikin acara yang bernuansa dakwah NU dan sarana sosialisasi kegiatan NU. Baik itu dalam bentuk pemutaran berita hasil liputan, maupun bentuk lain, seperti talkshow. Acara hiburan juga demikian. TV9 adalah media yang paling mengerti selera penontonnya yang sebagian besar adalah nahdliyin. Program acara hiburan yang ditayangkan tidak akan jauh dari hiburan yang disukai warga nahdliyin, seperti selawat Habib Syech, musik gambus dan sebagainya. Semuanya bernuansa dakwah NU. Hakim Jayli menjelaskan bahwa TV9 berusaha memberikan guidance kepada para nahdliyin atas hal-hal yang ingin diketahui dan dinikmati. Mulai dari keagamaan, sosial budaya, hingga berita dan informasi. ${ }^{28}$

Hakim Jayli tidak puas dengan hanya siaran melalui antena terestrial. Untuk menjangkau lebih besar lagi audiens, TV9 merambah ke satelit, televisi berlangganan dan streaming internet. Selain itu, TV9 juga masuk ke media sosial dan situs-situs pengunggah konten siaran video.

Tentu saja program-program acara tersebut tidak hanya untuk warga NU, melainkan juga untuk warga non-NU, bahkan non-muslim. Namun tujuannya tetap satu, yakni mendakwahkan ajaran-ajaran Islam ahlusunnah wal jamaah annahdliyah yang rahmatan lil alamin. ${ }^{29}$

\section{Dari Manajemen Ala NU Ke Penyiaran Modern}

Sebagai organisasi dengan jumlah pengikut terbesar di Indonesia dan hampir berusia satu abad, NU belum bisa diakui sebagai organisasi yang memiliki manajemen yang bagus. ${ }^{30}$

NU dan pesantren adalah dua hal yang tidak bisa dipisahkan. Berbicara tentang NU berarti berbicara tentang pesantren. Karena para pengurus dan tokohtokoh NU adalah orang pesantren dan memiliki pesantren. Hal itu juga berimbas pada manajemen organisasi di tubuh NU. Dalam struktur organisasi pesantren tradisional, peran kyai sangat menonjol. Gaya kepemimpinan sorang kyai

ditayangkan di TV, maka keluarlah gambarnya disertai suasana dan audiensnya. Biaya produksi yang paling terasa minim adalah karena tidak ada honor buat narasumber/ustadz pengisi acara.

${ }^{28}$ Wawancara dengan A. Hakim Jayli, 2 Desember 2018.

${ }^{29} \mathrm{Hal}$ itu juga ditegaskan KH Mutwakkil Alallah dan KH. Marzuki Mustamar (Ketua PWNU Jawa Timur periode 2018-2023) dalam beberapa sambutan dan pengajian. Bahkan KH Marzuki Mustamar memiliki jadwal khusus pengajian yang disiarkan dari kantor PWNU Jatim di Jl Masjid Al Akbar Timur Gayungsari setiap hari Sabtu selepas salat maghrib. Tema yang diangkat adalah seputar akidah ahlusunnah wal jamaah yang diterapkan di NU dan problematikanya.

${ }^{30}$ Sebagaimana disampaikan Sekjen PBNU Dr. Endang Turmudi, MA, yang dikutip NU Online di www.nu.or.id tertanggal 5 Desember 2005. Hal yang sama juga diungkapkan Ketua Umum PBNU KH Hasyim Muzadi sebagaimana dikutip LKBN ANTARA di antaranews.com tertanggal 13 Februari 2010. 
merupakan salah satu ciri khas atau bahkan menjadi bagian, meminjam istilah Gus Dur, subculture sebuah masyarakat tradisional (pesantren). Berbeda dengan gaya kepemimpinan lainnya, kyai pesantren sering kali menempati atau bahkan ditempatkan sebagai pemimpin tunggal yang mempunyai kelebihan (maziyah) yang tidak dimiliki oleh masyarakat pada umumnya. ${ }^{31}$

Mastuhu menemukan pola hubungan yang unik antara kyai dan santri. Pertama, pola hubungan otoriter-paternalistik. Yaitu pola hubungan antara pimpinan dan bawahan atau, meminjam istilah James C. Scott, patron-client relationship; dan tentunya sang kyailah yang menjadi pimpinannya. Sebagai bawahan, sudah barang tentu peran partisipatif santri dan masyarakat tradisional pada umumnya, sangat kecil, untuk mengatakan tidak ada; dan hal ini tidak bisa dipisahkan dari kadar kekharismatikan sang kyai. Seiring dengan itu, pola hubungan ini kemudian dihadapkan dengan pola hubungan diplomatik-partisipatif. Artinya, semakin kuat pola hubungan yang satu semakin lemah yang lainnya.

Kedua, pola hubungan laissez faire. Yaitu pola hubungan kyai santri yang tidak didasarkan pada tatanan organisasi yang jelas. Semuanya didasarkan pada konsep ikhlas, berkah, dan ibadah sehingga pembagian kerja antar unit tidak dipisahkan secara tajam. Seiring dengan itu, selama memperoleh restu sang kyai, sebuah pekerjaan bisa dilaksanakan. Pola hubungan ini kemudian diperhadapkan dengan pola hubungan birokratik. Yaitu pola hubungan yang pembagian kerja dan fungsi dalam lembaga pendidikan pesantren sudah diatur dalam sebuah struktur organisasi yang jelas. ${ }^{32}$

Meski demikian, kepemimpinan kharismatik paternalistik cenderung menunjukkan bobot rasa tanggung jawab kyai yang cukup besar perhatian secara pribadi terhadap para pengikutnya. Dengan demikian, kyai dapat memberikan pelindung sebaik-baiknya demi terjaganya persatuan dan kesatuan kelompok masyarakat yang dipimpinnya.

Kelemahan justru muncul pada saat gaya kepemimpinan ini terus diadopsi secara berkelanjutan. Kelemahan-kelemahan tersebut adalah tidak adanya kepastian tentang perkembangan pesantren disebabkan segala sesuatunya bergantung pada keputusan pimpinan. Selain itu adanya keraguan dan bahkan ketidakberanian tenaga-tenaga kreatif yang ikut membantu jalannya organisasi pesantren untuk ikut berperan aktif dalam menyumbangkan kreativitasnya. Juga tidak adanya perencanaan yang sistematis dalam proses pergantian kepemimpinan (pada umumnya pergantian kepemimpinan disebabkan oleh faktor alami, seperti kematian), dan tidak adanya peningkatan kualitas kepemimpinan seiring meningkatnya pengaruh sang kyai dari tingkat lokal sampai regional, atau bahkan

${ }^{31}$ Abdurrahman Wahid, Bunga Rampai Pesantren, (Jakarta: Dharma Bhakti, tt) hal. 168.

${ }^{32}$ Mastuhu, Dinamika Sistem Pendidikan Pesantren: Suatu Kajian Tentang Unsur dan Nilai Sistem Pendidikan Pesantren, (Jakarta: INIS, 1994), hal. 20-25. 
nasional.

Hakim Jayli juga mengakui bahwa SDM yang dimilikinya kebanyakan berasal dari pesantren dan memiliki latar belakang NU. Hal itu dilakukan agar memiliki visi yang sama dalam memperjuangkan dakwah NU. Selain itu, ada halhal teknis yang memang hanya kalangan pesantren dan NU yang paham dan terbiasa melakukannya seperti selawatan, istigasah dan sebagainya. Ia menceritakan pernah merekrut presenter dari lulusan perguruan tinggi umum yang bukan kalangan pesantren dan bukan dari warga NU. Ternyata ada banyak istilah dan pelafalan yang keliru saat on-air. Bahkan untuk melafalkan "Nahdlatul Ulama" saja kurang benar.

Nuansa manajemen pesantren juga dialami Hakim Jayli sebagai Direktur Utama TV9. Ia seringkali ditelepon kyai atau pengurus PWNU Jatim terkait dengan konten-konten yang dirasa kurang pas. Hakim bahkan menjelaskan dengan nada separuh canda: "Di sini (maksudnya TV9) ada dua komisi yang mengawasi siaran. Pertama, KPI, Komisi Penyiaran Indonesia. Kedua, KPU yaitu Komisi Penyiaran Ulama," ujarnya diiringi tawa. ${ }^{33}$

Namun beberapa tahun belakangan, tepatnya sejak dikerjasamakan dengan PT Siantar Top, manajemen TV9 mulai berbenah dan menerapkan prinsip-prinsip manajemen penyiaran. Kepala Divisi Operasional TV9, Sururi menjelaskan, pembenahan manajemen dilakukan terus menerus. Khususnya dalam menyesuaikan dengan prinsip-prinsip manajemen penyiaran. Sehingga, pelaksanaan produksi dan pengelolaan TV9 kini dilakukan secara profesional. Ia mencontohkan adanya prosedur tetap (protap) dalam pembuatan program acara, kegiatan dan sebagainya. $^{34}$

Meski demikian, peran para kyai dan pengurus PWNU Jatim tidak terlepas begitu saja. Untuk urusan konten dan narasumber, sejumlah kyai dan pengurus PWNU Jatim tetap turun tangan. Untuk keperluan ini, TV9 membuat sebuah program yang bernama 'Hujjah Aswaja', yakni program talkshow yang membahas tentang kegiatan dan isu-isu di PWNU Jatim. Narasumbernya kebanyakan adalah para pengurus PWNU Jatim atau Badan Otonom dan Lembaga di bawah naungan NU.

Sururi juga menjelaskan, penerapan manajemen modern di tubuh TV9 berdampak pada sistem penggajian para pegawainya. Kini, gaji tiap bulan tidak pernah telat. Dan semua karyawan digaji sesuai dengan beban kerja dan tanggung jawabnya, yang semuanya diukur oleh perusahaan.

${ }^{33}$ Wawancara dengan A. Hakim Jayli, 2 Desember 2018. Meskipun dengan nada canda, hal itu menunjukkan bahwa intervensi tidak hanya di tataran manajemen, melainkan juga sampai pada konten program acara. Bagi Hakim Jayli, hal ini harus direspon dengan baik karena budaya di pesantren santri harus taat kepada kyai.

${ }^{34}$ Wawancara dengan Sururi, 5 Desember 2018. 
Sururi lantas menceritakan proses manajemen yang sedang diberlakukan. Misalnya, sebuah program acara diawali dari perencanaan. Kemudian diatur sedemikian rupa terkait dengan siapa melakukan apa (perngoganisasiannya). Dan selanjutnya dilaksanakan (actuating) dan terakhir adalah mekanisme kontrol dan evaluasi yang selalu dilakukan. Bahkan, mulai tahun 2019, manajemen TV9 mulai menerapkan alat ukur berupa balanced scorecard. Yakni alat yang digunakan untuk mengukur kinerja suatu bisnis yang dilihat dari empat perspektif. Keempat perspektif itu terdiri dari perspektif keuangan, pelanggan, proses bisnis internal serta perspektif pertumbuhan dan pembelajaran. Tujuannya agar TV9 menjadi perusahaan yang lebih sehat dan terus berkembang. ${ }^{35}$

\section{Menebar Misi Menggapai Omzet}

Sejak awal berdiri, TV9 sudah menyatakan format dan positioning-nya. Lembaga penyiaran televisi ini memiliki format TV dakwah (religi) dengan positioning sebagai televisi dakwah yang menyiarkan konten-konten Islam rahmatan lil alamin. Format dan positioning ini kemudian dimunculkan dalam sebuah tagline atau semboyan "Santun Menyejukkan".

Hakim Jayli kembali menuturkan bahwa segala sesuatu yang dikerjakan oleh anak buahnya adalah buah dari perencanaan (planning). Dalam menjalankan perencanaan tersebut terdapat kegiatan yang harus dilakukan seperti segmentating, targetting, positioning, formatting, dan programming.

Meski sudah dinyatakan sebagai televisi dakwah yang menyiarkan kontenkonten NU, namun dalam brand positioning-nya TV9 lebih pada hal-hal unik, Islami, menghibur, edukatif, dakwah dan tradisional. Seperti diungkapkan Hakim Jayli bahwa positioning di market ini masih kosong. Ia membandingkan dengan beberapa televisi lokal di Surabaya, bahkan televisi Jakarta yang bersiaran di Surabaya tidak ada satupun yang mengambil positioning sebagai televisi religi. Misalnya JTV ataupun SBO TV yang sudah lama mengudara. Keduanya mengambil format hiburan dan news. Bahkan SBO lebih pada lifestyle. Sedangkan televisi religi hanya TV9.

Segmentasi TV9 menyasar pada semua kelompok SES (Social Economic Status). Baik A, B, maupun C, bahkan kelompok D dan E. ${ }^{36}$ Menurut Hakim Jayli,

${ }^{35}$ Menurut Sururi, pihak manajemen terlebih dulu menjelaskan kepada semua karyawan terkait dengan balanced scorecard. Sehingga nantinya bisa dipahami tolok ukur penilaian kinerja masing-masing. Bahkan, untuk penentuan beberapa hal yang terkait dengan kinerja, manajemen mendiskusikannya dengan karyawan.

36 SES disebut juga SEC (Social Economy Class), yakni pengelompokan segmen ini diukur daru jumlah pengeluaran rutin untuk membeli barang dan jasa seperti makanan dan minuman, biaya sekolah anak, biaya listrik, gaji pembantu, transportasi dan lainnya - tidak termasuk pengeluaran untuk kredit kendaraan atau rumah. Dalam lingkup riset pemasaran, SEC atau SES ini tergambar dalam 5 kelompok, yaitu: SES E, SES D, SES C, SES B dan SES A. Namun banyak versi yang berbeda dalam pengelompokan SES. Besaran SES juga berubah 
hal itu dilakukan karena TV9 lebih mengedepankan aspek psikografis audiensnya. ${ }^{37}$ Psikografis adalah identifikasi karakteristik kepribadian dan sikap yang memengaruhi gaya hidup seseorang dan perilaku pembelian. Psikografis mencakup pendapat, sikap, dan keyakinan tentang berbagai aspek yang berkaitan dengan gaya hidup dan perilaku pembelian. ${ }^{38}$

Hakim Jayli meyakini bahwa market dengan faktor psikografis lebih kuat daripada berdasarkan SES. Penonton TV9 adalah orang yang memiliki kepeminatan yang sama terhadap apa yang ditayangkan oleh TV9. Yakni terhadap religi, lebih khusus lagi yang ada hubungannya dengan NU. Mereka memiliki minat-minat tertentu terhadap religi. Untuk menyasar ke semua SES tersebut, ia merancang beberapa program khusus sesuai dengan SES-nya masing-masing. Misalnya untuk SES A dan B, dibikin program talkshow kebudayaan. Karena ia yakin, kepeminatan SES tersebut berada di model program tersebut. Termasuk tema-tema yang disukai kalangan SES A dan B.

Ia mengungkap data bahwa selama empat tahun terakhir telah terjadi perpindahan kelas ekonomi secara besar-besaran dari kelas bawah menuju kelas menengah. Angkanya sampai 60 persen. Bergesernya kelas ekonomi masyarakat ini juga dialami oleh para penonton TV9. Misalnya para guru madrasah yang mendapatkan sertifikasi. Awalnya gajinya kisaran Rp 300 ribu sampai Rp 600 ribu saja. Namun setelah mendapatkan sertfikasi gajinya naik menjadi di atas Rp 1,2 juta.

Selain masyarakat muslim, lebih khusus lagi masyarakat NU, market potensial audiens TV9 adalah kalangan muslim yang cocok dengan cita-cita dan perjuangan NU. Tidak terkecuali mereka yang dari non-muslim. Kelompok inilah yang dinamainya masyarakat kebangsaan, seperti para pengusaha non-muslim, kelompok Tionghoa dan sebagainya, yang selama ini mengidolakan Gus Dur. Bagi mereka, TV9 adalah representasi Gus Dur di udara. Ini semua adalah pasar yang sangat menarik bagi industri penyiaran untuk meraup keuntungan. Dampaknya sangat ia rasakan, dalam kisaran waktu empat tahun terakhir pendapatannya dari iklan terus naik.

Dengan potensi pasar yang besar ini Hakim Jayli bisa meyakinkan calon pemasang iklan/klien. Di satu sisi, positioning dan segmen yang jelas membuat TV9 tidak mengalami kesulitan yang berarti dalam mencari klien meskipun harus bersaing dengan televisi lokal lainnya. Karena kepemilikan saham yang sebagian dipunyai PWNU Jatim, TV9 bagi penontonnya adalah semacam pengakuan atas

seiring dengan perkembangan perekonomian masyarakat. Data AC Nielsen yang didapat untuk SES pada tahun 2014 adalah SES A1 > Rp 6,000,001; SES A2 Rp 4,000,001 - Rp 6,000,000; SES B Rp 2,500,001 - Rp 4,000,000; SES C1 Rp 1,750,001 - Rp 2,500,000; SES C2 Rp 1,250,001 - Rp 1,750,000; SES D Rp 900,001 - Rp 1,250,000; SES E<= Rp 900,000

${ }^{37}$ Wawancara dengan Hakim Jayli, 2 Desember 2018.

${ }^{38}$ James F. Engel, dkk, Perilaku Konsumen, (Jakarta: Binarupa Aksara, 1994), hal. 368. 
sebuah produk yang diiklankan.

"Mereka ini potensi klien kami, seperti umroh, perguruan tinggi yang agak mahal, sekolah unggulan. Nah, di NU, sekolah unggulan dan perguruan tinggi ini beriklan di kami. Seperti begini, umroh itu sekarang lebih senang beriklan di TV9, karena setelah diiklankan di TV9 ternyata lebih efektif. Karena beberapa klien mengatakan bahwa kalau sudah beriklan di TV9 itu $T V$-nya NU dan tidak mungkin apa yang tayang di TV9 tidak disetujui NU. Jadi, otomatis iklannya sudah dapat seperti sertifikasi halal. "39

Apapun industrinya, maka pasar adalah orientasi utama. Termasuk juga TV9. Pasar TV9 adalah warga NU. Begitu penegasan Hakim Jayli. Ia berusaha untuk mengelola pasar ini sebaik mungkin sehingga mendapatkan dua dampak sekaligus. Pertama dampak dakwah NU, yakni tersampaikannya misi NU kepada masyarakat. Kedua adalah dampak finansial, yakni semakin banyaknya iklan yang diraih. Bahkan Hakim Jayli berkeinginan agar semua warga NU yang menjadi audiens sekaligus 'pasar'-nya menjadikan TV9 sebagai pedoman untuk berbelanja.

"Jadi misalnya orang NU kalau mau umroh jangan kemana-mana, akan kami carikan. Kalau mau beli sepeda motor aku carikan yang cocok buat penonton, buat warga NU. Itu pula yang kami sampaikan kepada klien. Silakan bapak beriklan di tempat saya. Akan saya antarkan ke ceruk-ceruk pasar NU. Itu yang dianggap berbeda oleh principal atau agency. Kita dianggap paham bagaimana masuk pasar NU."

Satu hal lagi yang membuat TV9 bisa bertahan dan bahkan mendapatkan keuntungan, semua acara yang ditayangkan murni diproduksi sendiri oleh kru TV9. Hal ini tentu berpengaruh pada biaya produksi yang minim. Bahkan, untuk beberapa acara seperti Kiswah Event, TV9 hanya menurunkan kru yang sangat minim untuk melakukan perekaman acara.

\section{Kesimpulan}

Dari keseluruhan kajian strategi manajemen TV9 dalam bersaing dengan televisi lokal di Surabaya pada bab-bab sebelumnya, kajian ini menghasilkan temuan menarik.

Pertama, meski dimiliki dan dikelola oleh NU, sebagai entitas bisnis TV9 juga bertujuan mengejar profit. Manajemen TV9 dikelola dengan tujuan untuk mendapatkan pangsa pasar yang sebesar-besarnya dari warga muslim kota (urban moslem). Khususnya warga nahdliyin yang merupakan audiens terbesar di kota Surabaya dan sekitarnya. TV9 yang merupakan stasiun televisi lokal, mempunyai

${ }^{39}$ Wawancara A. Hakim Jayli, 2 Desember 2018. 
kecenderungan ditonton oleh masyarakat dari semua kalangan ekonomi (multisegmen). Untuk tujuan itu, TV9 merekrut karyawan berasal dari kalangan pesantren dan NU agar mampu mendesain program acara dengan karakteristik dan kepeminatan warga nahdliyin sehingga mendapatkan penerimaan yang positif. TV9 juga memberikan jaminan kepada pihak pengiklan bahwa produksi acara dan tayangannya tidak akan mendapatkan penolakan dari audiens. Hal itu sangat berpengaruh terhadap naiknya performance share and rating.

Kedua, proses dakwah yang menghibur sekaligus mendidik dengan menampilkan tokoh ulama yang terkenal lebih banyak diminati dan dinikmati oleh masyarakat. Narasumber acara yang ditampilkan adalah para dai dari kalangan NU yang memiliki pesantren, santri yang banyak dan berpengaruh di masyarakat. Hal inilah yang menjadi pertimbangan utama manajemen TV9 membuat program acara dakwah yang dikemas dengan fleksibel, ringan namun tak meninggalkan substansi dakwah. Manajemen TV9 menyesuaikan produksi program acara dengan kepeminatan dan aktivitas ritual spiritual audiens nahdliyin. Program acara yang dibikin adalah yang berkaitan dengan praktik keagamaan warga NU. Diantaranya mengikuti pengajian, selawatan, istigasah, tahlil, mengaji kitab dan sebagainya. Bahkan, TV9 juga mengejar momen-momen yang dinanti-nantikan oleh warga NU, seperti acara khaul ulama besar dan wali.

\section{Daftar Pustaka}

Brown, Robin. Boundaries in Question. Editor: John McMillan dan Andrew Linklater, USA: Pinter Publisher's London \& New York, 1995.

Carlisle, Howard M. Management Essentials: Concepts for Productivity and Innovation, 2nd Edition. Chicago: Science Research Associates, 1987.

Data TV9 dari survei AC Nielsen pada tahun 2014.

Database pendaftaran lembaga penyiaran KPID Jawa Timur periode 21 Oktober-21 Desember 2007.

Database Perizinan KPID Jawa Timur tahun 2016.

Djuroto, Totok. Manajemen Penerbitan Pers. Cet. III. Bandung: Remaja Rosdakarya, 2004.

Dawud, Mochammad. Menerapkan Manajemen Strategi Penyiaran untuk Penyiaran Dakwah. Jurnal Al-Hikmah, 2019, 17.1: 109-140.

Elanda, Yelly. Komodifikasi Agama pada Perumahan Syariah di Surabaya. Jurnal Al-Hikmah, 2019, 17.1: 41-62.

Emzir. Metodologi Penelitian Pendidikan Kuantitatif dan Kualitatif. Jakarta: Rajawali Pers, 2008.

Engel, James F., dkk. Perilaku Konsumen. Jakarta: Binarupa Aksara, 1994.

Fairclough, Norman. Change and Hegemony dalam Critical Discourse Analysis. London: Longman, 1998. 
Manajemen Strategi Ala NU TV9 Menghadapi Televisi Swasta...

Fairclough, Norman. Introduction, dalam Norman Fairclough (ed), Critical Language Awarenes. New York: Longman, 1992.

Faisal, Sanapiah. Format-format Penelitian Sosial. Jakarta: Raja Grafindo Persada, 2001.

Giddens, Anthony. Teori Strukturasi: Dasar-dasar Pembentukan Struktur Sosial Manusia, terjemahan Maufur \& Daryanto. Yogyakarta: Pustaka Pelajar. 2010.

Golding, Peter and Graham Murdock. The Political Economy of Media. Volume I, Cheltenham, UK. Brookfield, US: The International Library of Study and Culture, 1997.

Hamad, Ibnu. Konstruksi Realitas Politik Dalam Media Massa. Jakarta: Granit, 2004.

Handoko, T. Hani. Manajemen Edisi II. Yogyakarta: BPPE, 1994.

Hariono, Budi. Dalam Bingkai Media Massa. Surabaya: Papyrus, 2004.

Hadi, H. Sofyan. Manajemen Strategi Dakwah di Era Kontemporer. Jurnal AlHikmah, 2019, 17.1: 79-90.

Isfironi, Mohammad. Kota Santri, Bumi Shalawat Nariyah dan Bule-Dhika. Jurnal Al-Hikmah, 2019, 17.1: 1-20.

Jannah, Hasanatul. Pondok Pesantren Sebagai Pusat Otoritas Ulama Madura. Jurnal Al-Hikmah, 2019, 17.1: 91-108.

Jayli, Hakim. Televisi Kaum Santri: Konsep Baru Bisnis dan Tayangan Televisi di Gerbang Era Televisi Digital. Surabaya: TV9 Nusantara, 2012.

Kaoey, Rahman. Pedoman Pelaksanaan Dakwah Islam. Yogyakarta: Penerbit AK Group Yogyakarta, 2006.

Kasali, Rhenald. Membidik Pasar Indonesia. Jakarta: PT Gramedia Pustaka Utama, 2004.

Keputusan Menteri Perhubungan Nomor 76 tahun 2003 tentang Frekuensi TV Analog.

Kotler, Philip dan Gary Armstrong. Marketing Management. Jakarta: Prenhallindo, 2001.

Kotler, Philip. Manajemen Pemasaran. Jakarta: Erlangga, 2009.

Kriyantono, Rachmat. Riset Komunikasi. Cet. V. Jakarta: Kencana Prenada Media Group, 2010.

Masduki. Menjadi Broadcaster Professional. Yogyakarta: LKiS Pelangi Aksara, 2004.

Mastuhu. Dinamika Sistem Pendidikan Pesantren: Suatu Kajian Tentang Unsur dan Nilai Sistem Pendidikan Pesantren. Jakarta: INIS, 1994.

McQuail, D. Mass Communication Theories. London, UK: Sage Publication, 2010.

Effendi, Onong Uchjana. Dinamika Komunikasi. Bandung: Remaja Rosdakarya, 2008. 
Moleong, Lexy J. Metodologi Penelitian Kualitatif. Bandung: Remaja Rosdakarya, 2002.

Morissan. Manajemen Industri Media Penyiaran: Strategi Mengelola Radio dan Televisi. Jakarta: Kencana, 2009.

Mosco, Vincent. The Political Economy of Communication. Singapore: SAGE Publications Asia-Pacific, 2009.

Muhadjir, Noeng. Metodologi Penelitian Kualitatif. Yogyakarta: Reka Serasin, 2000.

Muis. Komunikasi Islami. Bandung: PT Remaja Rosdakarya, 2001.

Nafis, Muhammad Wahyu. Rekonstruksi The Modern World, Religius Islam. Jakarta: Paramadina, 1996.

Narbuko, Cholid, Abu Achmadi. Metodologi Penelitian. Jakarta: Bumi Aksara, 2002.

Nawawi, Hadari. Manajamen Sumber Daya Manusia untuk Bisnis yang Kompetitif. Yogyakarta: Gajah Mada University Press, 2003.

Nazir, Mohammad. Metode Penelitian. Bogor: Ghalia Indonesia, 2005.

Peraturan Menteri Komunikasi dan Informatika nomor 28 tahun 2008 tentang Tata Cara Penyelenggaraan Penyiaran

Pringle, Charles D., Daniel F. Jennings and Justin G. Longenecker. Managing Organizations: Functions and Behaviors. Columbus, Ohio: Merrill Publishing Co., 1988.

Pringle, Peter K., Michael F. Star. Electronic Media Management (Fifth Edition). Boston: Focal Press, 2006.

Robbins, Stephen P. Organizational Behavior, 9th Ed. New Jersey: Prentice Hall International, 2001.

Robinson, Pearch. Manajemen Startegik: Formulasi, Implementasi, dan Pengendalian. Jakarta: Binarupa Aksara, 1997.

Schoderbek, Peter P., Richard A. Cosie, and John A. Aplin. Management Systems: Conceptual Considerations, 3rd Edition. Business Publication, 1985.

Sobary, Mohammad. NU dan Ke-Indonesiaan. Jakarta: Gramedia Pustaka Utama, 2010.

Spencer, L.M and Spencer, S.M. Competence at Work. Toronto: John Wiley \& Sons, Inc, 1993.

Suhandang, Kustadi. Manajemen Pers Dakwah. Bandung: Marja, 2007.

Sule, Ernie T. \& Kurniawan. Pengantar Manajemen. Jakarta: Kencana, 2006.

Sutisna. Perilaku Konsumen dan Komunikasi Pemasaran. Bandung: Remaja Rosdakarya, 2001.

Suwandyanto, M. Manajemen Strategi dan kebijakan Perusahaan. Jakarta: Salemba Empat, 2010.

Syahputra, Iswandi. Rezim Media: Pergulatan Demokrasi, Jurnalisme dan 
Manajemen Strategi Ala NU TV9 Menghadapi Televisi Swasta...

Infotainment Dalam Industri Televisi. Jakarta: Gramedia Pustaka Utama, 2013.

Undang-Undang Nomor 32 tahun 2002 tentang Penyiaran.

Wahid, Abdurrahman. Bunga Rampai Pesantren. Jakarta: Dharma Bhakti, tt.

Wazis, Kun. Perlawanan Ahli Hadis terhadap Gerakan Radikalisme Dalam Konstruksi Media Online. Jurnal Al-Hikmah, 2019, 17.1: 20-40.

Wawancara dengan A. Hakim Jayli, 2 Desember 2018.

Wawancara dengan Sururi, 5 Desember 2018.

Williams, Raymond. Televisi, terjemahan dari buku Television: Technology and Cultural Form. Yogyakarta: Resist Book, 2009.

www.alexa.com. Diakses 1 Desember 2018

www.antaranews.com tertanggal 13 Februari 2010. Diakses tanggal 10 Desember 2018.

www.nu.or.id tertanggal 5 Desember 2005. Diakses tanggal 10 Desember 2018 